\title{
Commentary
}

\section{FIFA, Qatar, Kafala: Can the World Cup Create a Better World of Work?}

\author{
By Beryl ter Haar, Assistant Professor on European and International Labour \\ Law, Leiden University, The Netherlands
}

\section{Introduction}

The global trade union federation Building and Wood Worker's International (BWI) raised a specific instance with the Swiss National Contact Point (NCP) of the Organisation for Economic Co-operation and Development (OECD) concerning human rights violations of migrant workers related to the construction of facilities for the 2022 World Cup of the Fédération Internationale de Football Association (FIFA). BWI raised nine issues. These included a due diligence policy for FIFA to commit to the ILO Core Conventions, the UN Guiding Principles of Business and Human Rights, and the OECD Guidelines as part of the criteria for bids by countries wishing to host the FIFA World Cup. They also included a human rights impact assessment and use of FIFA's considerable leverage to engage with the Qatari government to accelerate labor and human rights related reforms, especially the abolishment of the Kafala system. In its responding statement, FIFA first questioned whether the OECD Guidelines even apply to it, given that it is an association rather than a business. Regarding its leverage over the Qatari government, FIFA indicated that its direct counterparty is not the Qatari government but instead the member association, the Qatar Football Association. Regarding labor standards, FIFA follows International Organization for Standardization (ISO) 26000 guidance for social responsibility and ISO 20121 standards for event sustainability management systems. Sustainability reporting adheres to Global Reporting Initiative (GRI) guidelines and stakeholder engagement is based on AA10oo Stakeholder Engagement Standard. More specifically, FIFA indicates that its

(C) TER HAAR, 2018 | DOI 10.1163/24056901-00401019

This is an open access article distributed under the terms of the prevailing CC-BY-NC License at the time of publication 
Quality Programme includes ethical business practices in terms of child labor, working hours, health and safety requirements, which are based on the code of conduct of the World Federation of the Sporting Goods Industry (WFSGI). Last, FIFA states that future biddings will follow the United Nations Guiding Principles on Business and Human Rights (UNGP).

Having established the identity and interest of the parties and its own competence, the NCP addressed the issue whether the OECD Guidelines are applicable to FIFA. First the NCP reiterated the broad definition of multinational enterprise cited in the OECD Guidelines, a definition that includes enterprises in all sectors of the economy; permits private, state, or mixed ownership; and usually involves companies or entities established in other countries. Further, the NCP asserted that the Guidelines expressly establish principles and standards for responsible business conduct, which is generally understood as the responsibility of entities involved in business or commercial activities. Whether an entity can be considered to have commercial activities is to be determined by the competent NCP on a case-by-case analysis based on the circumstances. To understand the FIFA context, the NCP's next step was therefore first to ascertain its legal structure. FIFA is not a single legal entity, but comprises several, which are listed in the Commercial Register of the Canton of Zurich. FIFA also owns a number of foreign subsidiaries. The second consideration relates to the sort of activities FIFA undertakes. For this determination, the NCP analyzed the bidding contract between FIFA and its direct counterparties in Qatar. The contract is comprehensive and includes various commercial elements, among them media marketing rights, finance, and insurance. The NCP's conclusion is therefore that the OECD Guidelines are applicable, for three reasons: FIFA includes different entities active in more than one country, has a multinational scope, and undertakes commercial activities.

Having established that the OECD Guidelines are applicable, the NCP can offer its function as mediator to deal with the merits of the specific instance, that is, decent and safe working conditions for migrant workers involved with building stadiums and related facilities and infrastructure for the 2022 World Cup. Under auspicious of the Swiss NCP, BWI and FIFA reached agreement on five areas identified as relevant: first, identification and use of FIFA's leverage on relevant actors in Qatar; second, the human rights policy invoked the new Article 3 of the FIFA Statutes; third, a robust process of monitoring labor conditions; fourth, mechanisms for worker complaints and grievances; and, fifth, establishment of an oversight-advisory body. BWI and FIFA concurred on the need for continued regular dialogue between them. They also agreed to meet again with the Swiss NCP nine months after the publication of the final statement. 


\section{The Kafala System}

FIFA's decision to grant the 2022 World Cup to Qatar has been met with much disapproval worldwide by various organizations, including human and labor rights entities. Some of the disapproval relates to scandals concerning corruption within FIFA. ${ }^{1}$ Some is linked to the Kafala system. Kafala, which means sponsorship in Arabic, is a system of control. In the context of migrant workers in Arabic countries, Qatar among them, it is a system in which governments have delegated oversight and responsibility for migrant workers to private citizens and companies. ${ }^{2}$ Sponsors are granted legal powers to control migrant workers; for example, a worker cannot change his job, quite his job, or leave the country without the employer's permission. Further, an employer has the authority to cancel the residence visa of a worker who quit his or her job without permission. In doing so, such a worker immediately becomes an illegal resident in the country, often providing cause for deportation proceedings, which can include prison time.

The advocacy organization Migrant-Rights.org argues that Kafala is more a matter of security rather than a labor issue. To a certain extent, this is understandable given that the population of migrant workers in Qatar is often higher than that of than inhabitants. In the run-up to the World Cup, for example, it is estimated at 94 percent. $^{3}$ In this context, it has been argued that leaving the Kafala system might disrupt Qatari society too much. A fear among the Qatari is that under a less strict regime, migrant workers would unite, coalesce, and perhaps even mobilize against them. ${ }^{4}$ That the Kafala system puts migrant workers in a particularly vulnerable position is to a certain extent therefore with intent. The vulnerability is evident in many aspects of work. One is an initial payment of about $\$ 3,000$ to the recruitment agency. The idea is that this amount can easily be repaid with the better wages the worker will receive. Unfortunately, reassignment to another job that pays considerably less is common among migrant workers. In addition, migrant workers are often required to work long hours but get no time off. Moreover, health and safety is even more an issue and in jeopardy when it comes to the construction of the stadiums, roads, and other buildings needed for the World Cup, because

1 See, for example, Jonathan Liew, "World Cup 2022: Qatar's workers are not workers, they are slaves and they are building mausoleums, not stadiums," The Independent, 3 October 2017.

2 For a full explanation of the Kafala system, see "Understanding Kafala: An Archaic Law at Cross Purposes with Modern Development," 11 March 2015, www.migrant-rights.org.

3 “The Middle East's migrant workers. Forget about rights," The Economist, 10 August 2013.

4 Ibid. 
the statutory breaks imposed during summer midday hours are not adequate protection. ${ }^{5}$

In these circumstances, the Kafala system is especially harmful to migrant workers. First, they are not allowed to organize, which deprives them of the ability to change their working conditions and improve the health and safety at construction sites. Second, they cannot leave their employment, mainly because their passports are typically confiscated, but also because of their debt to the recruitment agency. In addition are the risks of imprisonment for leaving their sponsor without authorization and of immediate deportation. ${ }^{6}$ Statistical data indicate that the 2022 World Cup is already the most deadly of all such events: 1,200 deaths are associated with World Cup related construction sites. The sixty fatal accidents at the 2014 Olympic Games in Sochi were already extreme relative to ten for the 2014 World Cup in Brazil, two for the 2010 World Cup in South Africa, and one for the 2012 Olympics in London. ${ }^{7}$ How many workers really died due to poor working conditions at the constructions sides is unclear, partly because it is very difficult to get this information and the information that is gathered is distorted. Many of the deaths are not investigated, for example, often because they are attributed to natural causes, such as cardiac arrest or respiratory failure, rather than the actual dehydration or heat stress. ${ }^{8}$

\section{Actions to Change the Working Circumstances in Qatar}

The specific instance BWI initiated with the Swiss NCP is one of many to pressure the Qatari government to abolish the Kafala system. The Dutch trade union FNV, for example, together with two other trade unions and a migrant worker from Bangladesh also initiated a case against FIFA. The claim was similar to this specific instance, namely, that FIFA should fulfil its responsibility to ensure better working circumstances for the migrant workers at World Cup construction sites. On 6 January 2016, the Swiss court rejected the claims of FNV c.s. on the grounds that they were too vague and therefore not admissible. ${ }^{9}$

5 Cf. David Conn, "Thousands of Qatar World Cup workers 'subjected to life-threatening health," Guardian, 27 September 2017.

6 Liew, "World Cup 2022."

7 Cf. www.statista.com/chart/3504/fifas-corruption-also-has-a-human-cost/.

8 Cf. Conn, "Thousands of Qatar World Cup workers"; see also Wesley Stephenson, "Have 1,200 World Cup workers really died in Qatar?” ввс Magazine, 6 June 2015, www.bbc.com/news/ magazine-33019838.

9 Unfortunately the judgment is not publicly available. See for the claims though: Tomáš Grell, "FIFA's Responsibility for Human Rights Abuses in Qatar - Part I: The Claims against FIFA", 
International organizations like the $\mathrm{ILO},{ }^{10}$ nongovernmental organizations such as Human Rights Watch ${ }^{11}$ and Amnesty International, ${ }^{12}$ and the (international) press are also pressuring Qatar. With the exception of the FNV case, however, these initiatives are all forms of soft law or soft jurisprudence. ${ }^{13}$ They do, however, demonstrate the importance of trade unions and the ability to organize transnationally and initiate actions based on transnational solidarity. It is because of their efforts and actions that these soft law initiatives, if slowly, seem to pay off in hard reforms. First, in May 2017 FIFA adopted a Human Rights Policy based on the United Nations Global Compact principles and the Ruggie Framework, which covers activities in countries hosting World Cups. ${ }^{14}$ Second, Qatar has vowed to adopt changes in the Kafala system to make it less susceptible to practices that amount to modern slavery. ${ }^{15}$ Although the future will reveal how serious these promises are, the first steps have been taken and there is no retracing them. If the reforms prove to be serious and are followed up by others, the 2022 World Cup will bring the world more than just a great sports event. It will make Qatar, Qatar World Cup construction sites, and future World Cup construction sites a safer and healthier work place for workers, migrant and domestic.

Asser International Sports Law Blog, 28 February, 2017. See for a more elaborate discussion of this case in comparison with the currently discussed Swiss OECD NCP: Beryl ter Haar, "FIFA 2022 World Cup and Labour Rights - Seizing the moment for labour law reforms in Qatar", Kutafin University Law Review (forthcoming 2018).

10 See, among others, Complaint concerning non-observance by Qatar of the Forced Labour Convention, 1930 (No. 29), and the Labour Inspection Convention, 1947 (No. 81), made by delegates to the 103rd Session (2014) of the International Labour Conference under Article 26 of the ILO Constitution. This complaint is followed by a three-year technical cooperation program in Qatar ("ILO Governing Body welcomes Qatar's commitment to bolster migrant worker rights," Press Release, 8 November 2017, www.ilo.org/global/aboutthe-ilo/newsroom/news/WCMS_592473/lang--en/index.htm).

11 See Human Rights Watch, "Qatar," www.hrw.org/middle-east/n-africa/qatar.

12 See, for example, Amnesty International, "Qatar World Cup of Shame," www.amnesty.org/ en/latest/campaigns/2016/o3/qatar-world-cup-of-shame/\#.

13 Soft jurisprudence is a term used by employer organizations to describe the effect of the supervisory mechanism of the ILo. See Claire La Hovary, “The ILO's Supervisory Bodies' 'Soft Law Jurisprudence,", in Research Handbook on Transnational Labour Law, ed. Adelle Blackett and Anne Trebilcock (London: Edward Elgar, 2015).

14 For the policy document, see "FIFA publishes landmark Human Rights Policy," 8 June 2017, www.fifa.com/governance $/$ news $/ \mathrm{y}=2017 / \mathrm{m}=6 /$ news=fifa-publishes-landmark-human -rights-policy-2893311.html.

15 "BWI Welcomes New Commitments in Qatar," Press Release, 28 October 2017, www.bwint .org/cms/news-72/bwi-welcomes-new-commitments-in-qatar-846. 